\title{
Ethanol locks for the prevention of catheter-related bloodstream infection: a meta-analysis of randomized control trials
}

\author{
Peng Zhang(D, Jun-Hao Lei, Xin-Jun Su* (D) and Xing-Huan Wang
}

\begin{abstract}
Background: Current evidence regarding the efficacy of ethanol locks in preventing catheter-related bloodstream infection (CRBI) is inconclusive.

Methods: Electronic databases, including PubMed, Web of Science, Embase, and the Cochrane Library (until April 2018),were systematically searched for relevant studies. Two reviewers independently screened the retrieved records and identified RCTs that met the inclusion criteria. Relevant data were extracted for pooled analyses using Review Manager 5.3 software. Subgroup analysis was performed according to the study quality, duration of the ethanol lock, disease type and CRBI definition. Eggs' method was applied to detect publication bias. Sensitivity analysis was conducted to check the stability of the meta-analysis results.

Results: Ten RCTs involving 2760 patients were included in the analysis. The overall pooled result indicated that ethanol locks significantly reduced the incidence of CRBI (RR 0.66, 95\% Cl 0.51-0.86). Subgroup analysis suggested that an ethanol lock significantly decreased the incidence of CRBI in patients with hematological diseases (RR 0.50, 95\% Cl 0.31-0.80). An ethanol lock significantly reduced the incidence of CRBI in a2-hour ethanol lock group (RR 0. $49,95 \% \mathrm{Cl} 0.33-0.73)$. The meta-analysis showed that an ethanol lock significantly reduced the incidence of CRBI according to analysis of high-(RR $0.66,95 \% \mathrm{Cl} 0.47-0.94)$ or low-(RR $0.66,95 \% \mathrm{Cl} 0.46-0.95)$ quality studies. Metaanalysis of studies with a strict CRBI definition showed that an ethanol lock can significantly prevent CRBI (RR 0.61, $95 \% \mathrm{Cl} 0.42-0.89$ ). The results of sensitivity analysis suggested that the pooled result was stable. Meta-analysis of adverse events showed that an ethanol lock did not increase the incidence of thrombosis (RR 1.05, 95\% Cl 0.51-2. 18) or mortality (RR $0.99,95 \% \mathrm{Cl} 0.90-1.08$ ) but did result in increased nausea (RR $1.54,95 \% \mathrm{Cl} 1.01-2.35$ ), dizziness (RR 4.21, 95\% Cl 2.40-7.39),elevated blushing rates (RR 3.27, 95\% Cl 2.05-5.22) and altered taste rates (RR 2.61, 95\% Cl 1.93-3.54).
\end{abstract}

Conclusions: An ethanol lock may play a role in the prevention of CRBI, especially in immunocompromised patients with hematological diseases.

Keywords: Catheter-related bloodstream infection, Ethanol lock, Meta-analysis

\footnotetext{
* Correspondence: 1919519046@qq.com; wangxinghuan@whu.edu.cn Department of Urology, Zhongnan Hospital, Wuhan University, 169 Donghu load, Wuchang district, Wuhan 430071, Hubei, People's Republic of China
}

(c) The Author(s). 2018 Open Access This article is distributed under the terms of the Creative Commons Attribution 4.0 International License (http://creativecommons.org/licenses/by/4.0/), which permits unrestricted use, distribution, and reproduction in any medium, provided you give appropriate credit to the original author(s) and the source, provide a link to the Creative Commons license, and indicate if changes were made. The Creative Commons Public Domain Dedication waiver (http://creativecommons.org/publicdomain/zero/1.0/) applies to the data made available in this article, unless otherwise stated. 


\section{Background}

Tunneled central venous catheters $(\mathrm{CVCs})$ are widely used for long-term venous access to deliver blood and its products, chemotherapy and parenteral nutrition [1]. However, despite improved international guidelines on $\mathrm{CVC}$ placement and catheter care, the use of $\mathrm{CVCs}$ carries a high risk of developing catheter-related bloodstream infection (CRBI) [2]. Furthermore, CRBIs are related to increased healthcare costs, morbidity, hospitalization and death [3].

There are many ways to reduce CRBIs, including antimicrobial lock solutions, catheter care procedures, and agents that reduce nasal colonization of Staphylococcus aureus, and one meta-analysis showed that antimicrobial lock solutions significantly reduce the risk of CRBI [4]. Overall, ethanol locks are considered a promising lock solutions because they are inexpensive, universally available, and effective against a broad spectrum of bacteria and fungi [5]. Nevertheless, study results to date on ethanol locks are controversial.

For example, Bertrand Souweine et al. observed that a 2-min ethanol lock does not decrease the frequency of infection of dialysis catheters(DCs) in intensive care unit (ICU) patients [6]. A randomized pilot study showed that a $30 \%$ ethanol $/ 4 \%$ sodium citrate appears to prevent CRBI and may improve catheter survival compared to heparin [7], and a randomized controlled multi-center trial showed that ethanol locks can prevent CRBI in pediatric oncology patients [8]. However, ethanol lock therapy has not been observed to affect patients after major heart surgery (MHS) [9].

Here, we present the results of a meta-analysis to investigate the association between ethanol locks and CRBI.

\section{Methods}

This study was performed according to the preferred reporting items of the systematic review and meta-analysis (PRISMA) guidelines.

\section{Systematic search strategy}

We conducted an electronic search of the PubMed (1966 to April2018), Embase (1974 to April2018), Science Citation Index (1974 to April 2018) and Cochrane (April 2018) databases for relevant studies on the efficacy of ethanol locks in preventing CRBI.

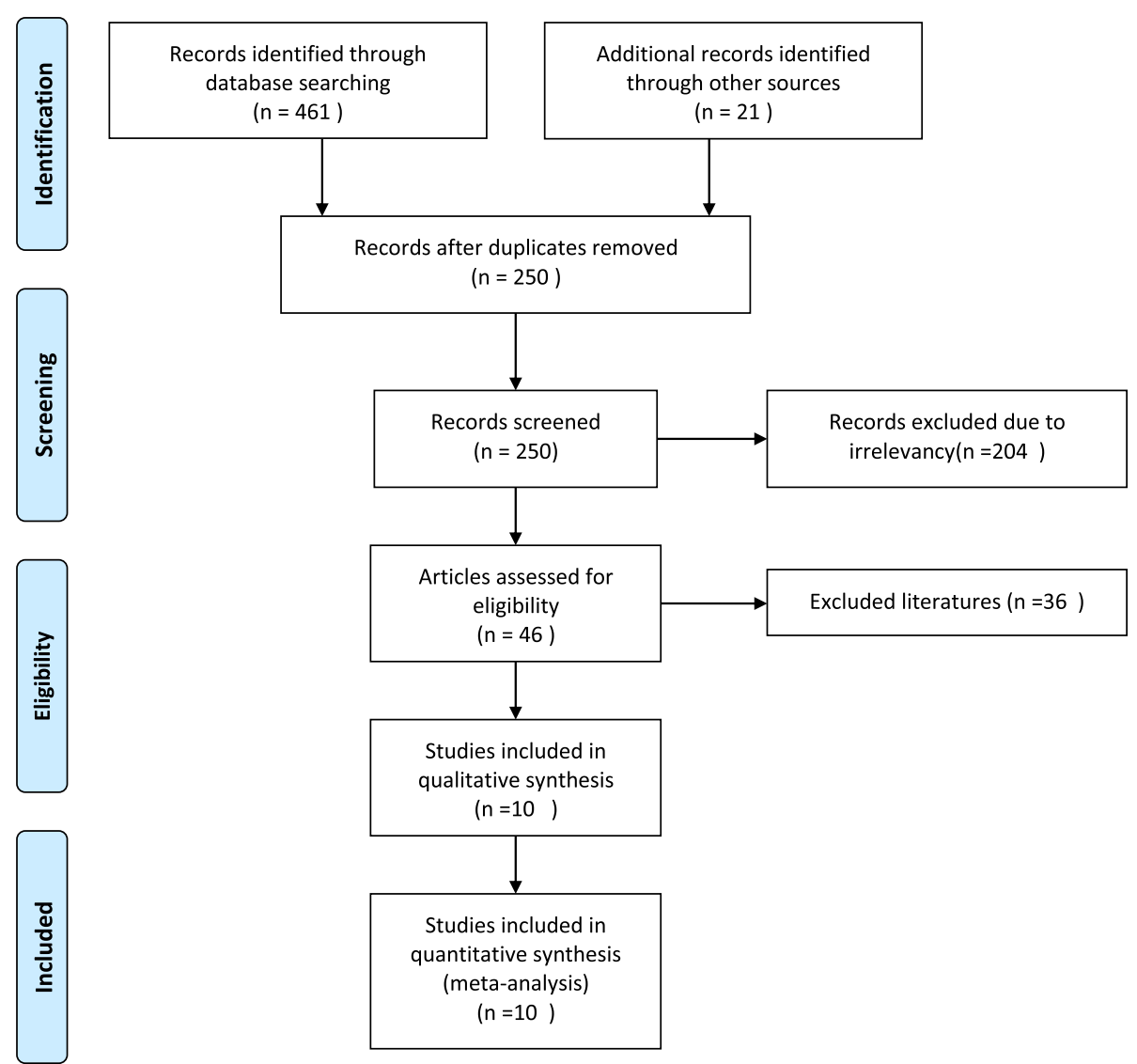

Fig. 1 PRISMA flow diagram 


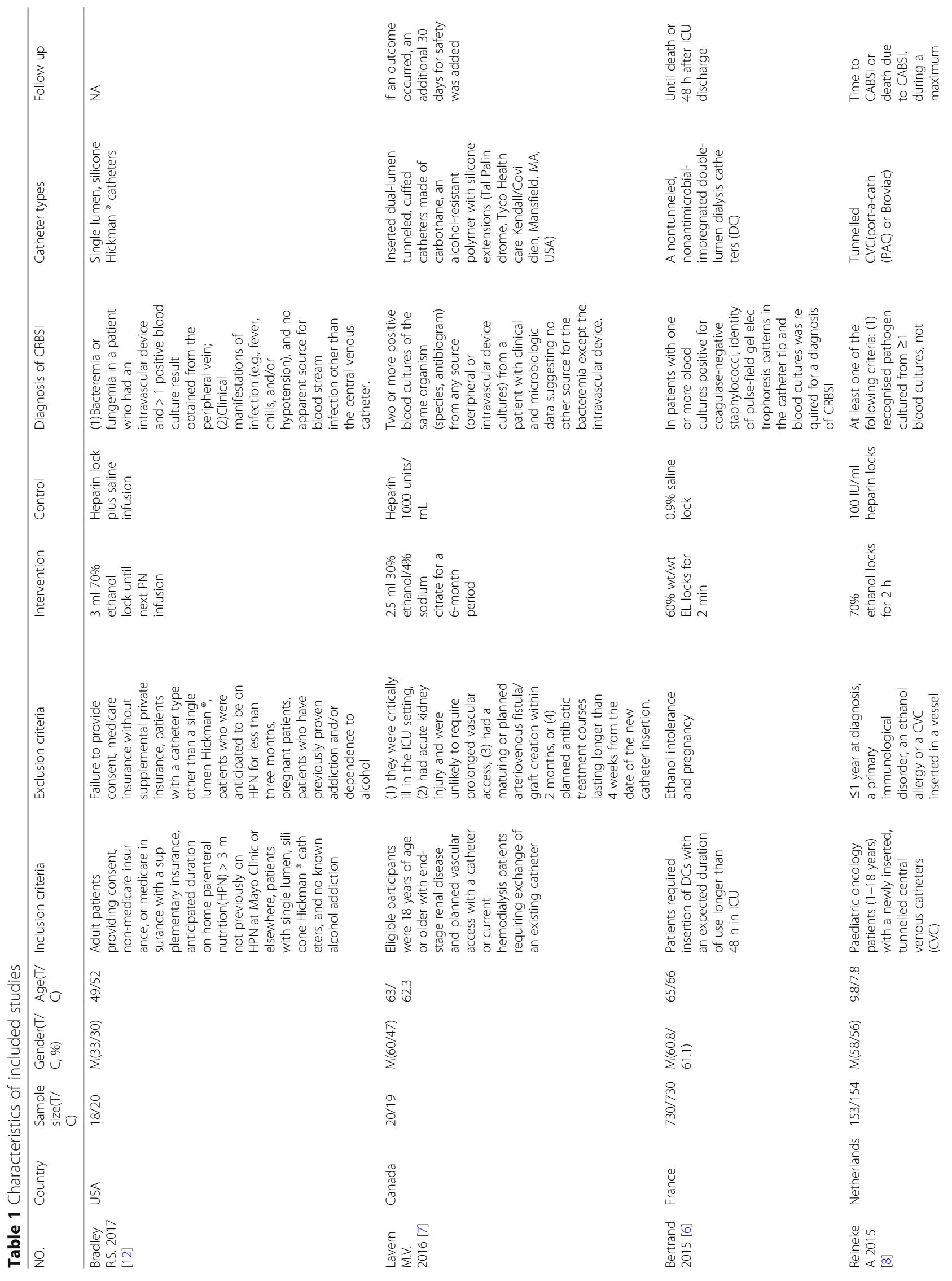




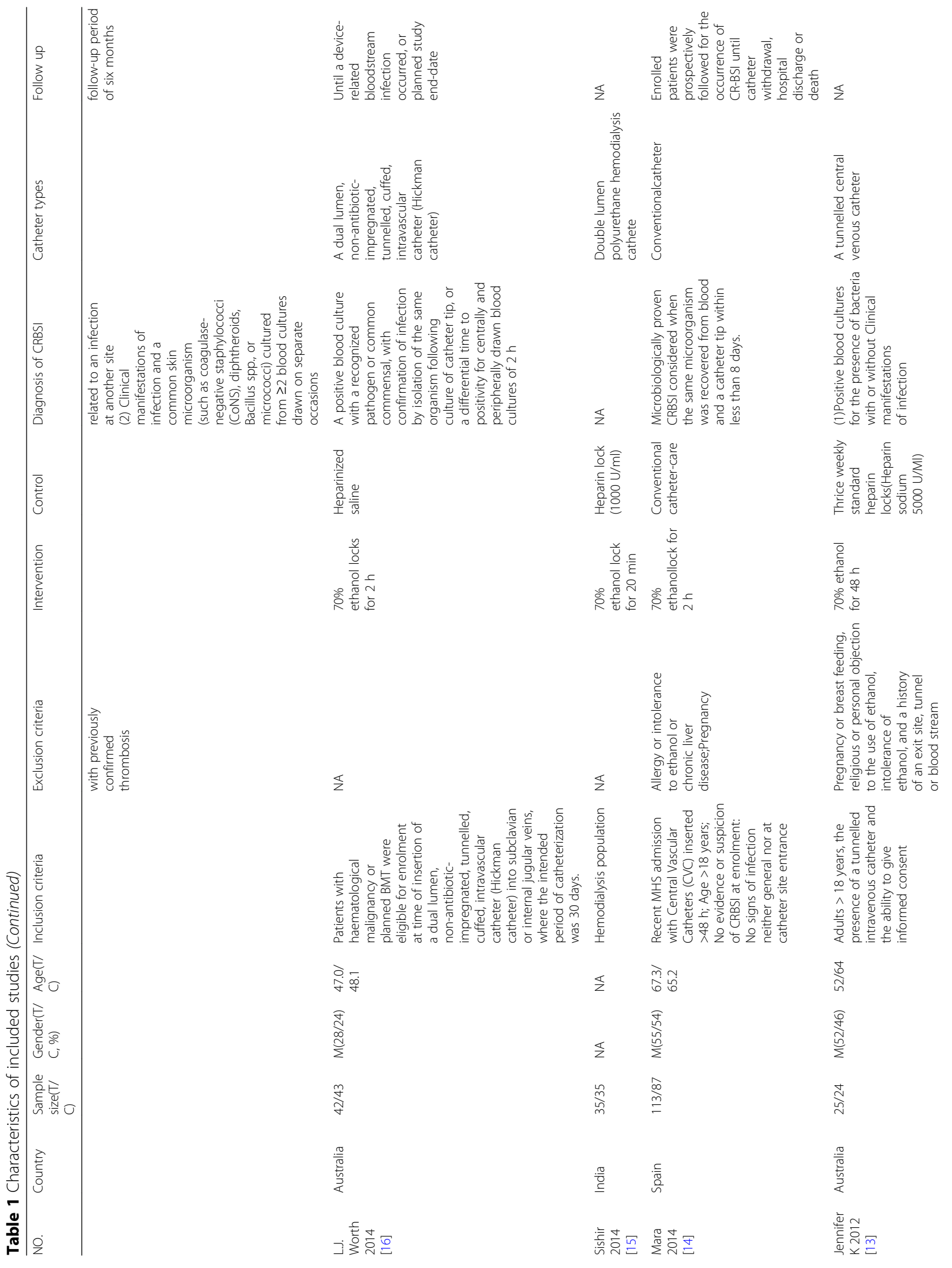




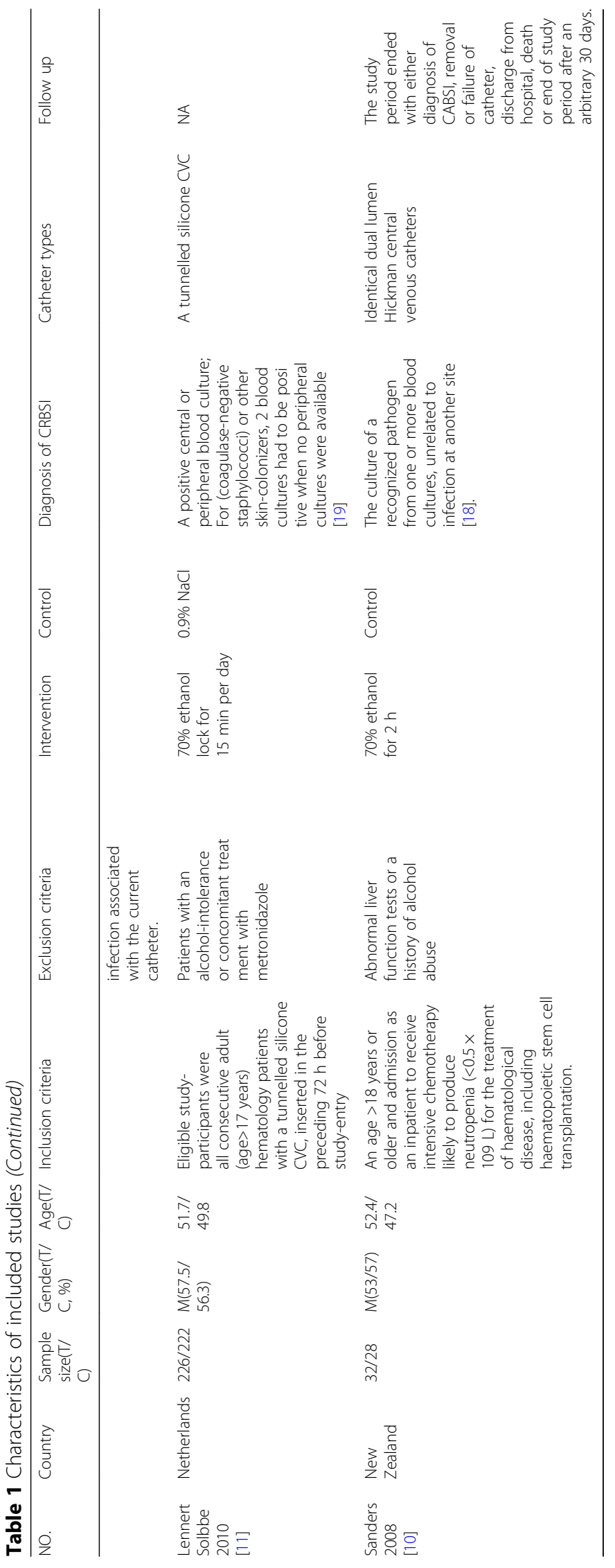




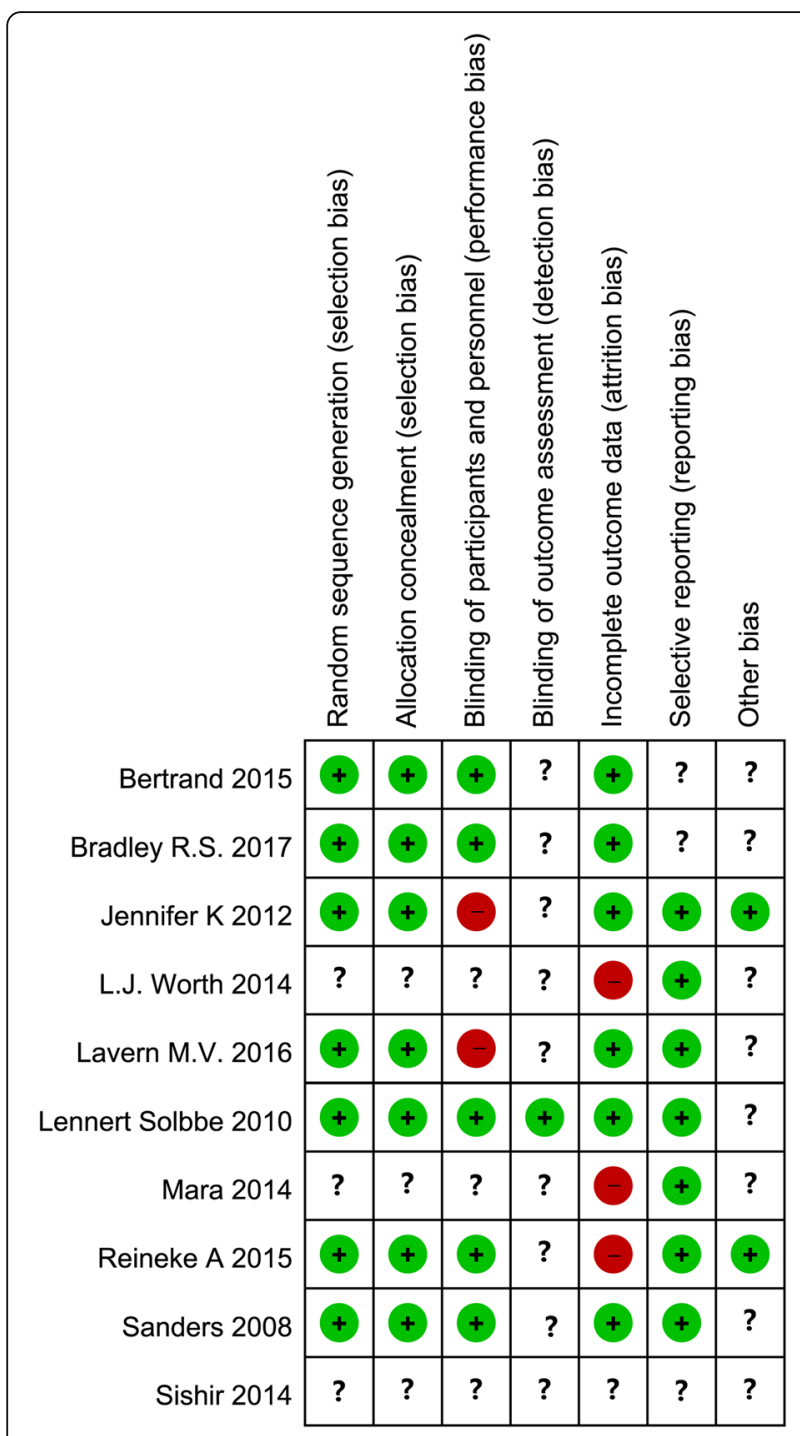

Fig. 2 Risk of bias assessment for the included RCTs

The two keywords used to search the above electronic databases were 'ethanol lock' and 'infection.' All reference sections of eligible studies were hand-reviewed for potential inclusion, and no limits on language were imposed.

\section{Eligibility criteria}

We included studies if they met the following criteria: (1) study participants were patients with indwelling central venous catheters,(2) the intervention group received ethanol locks and the control group heparin/ $\mathrm{NaCl}$ locks, and (3) the studies were randomized controlled trials (RCTs).

\section{Study selection and data extraction}

Two reviewers independently screened and assessed titles and abstracts to confirm whether the inclusion criteria were met. Data, including study characteristics (title, publication time, and sample size), detailed information in the PICOS approach (participant, intervention, comparison, outcomes, and study design), and other characteristics, were extracted by two authors using standard data extraction forms. Where necessary, the authors of the original studies were contacted for missing information.

\section{Methodological quality assessment}

The Cochrane Collaboration tool for assessing the risk of bias was used to evaluate the methodological quality of each included RCT. There were seven items for assessing bias including random sequence generation (selection bias), allocation concealment (selection bias), blinding of participants and personnel (performance bias), blinding of outcome assessment (detection bias), incomplete outcome data (attrition bias), selective reporting (reporting bias) and other biases. Each item was categorized as a low risk of bias, an "unclear" (either lack of information or uncertainty about the potential for bias) risk of bias, or a high risk of bias under the guidelines in the Cochrane Handbook.

\section{Data synthesis and analysis}

The meta-analysis was performed using Review Manager 5.3 software based on PRISMA guidelines. Heterogeneity was assessed by examining the clinical characteristics of the included studies and by formal statistical $X^{2}$ and $\mathrm{I}^{2}$ tests. For main outcomes (incidence of CRBI), Mantel-Haenszel estimates with a random-effects analytical model (due to the considered between-trial heterogeneity) were used to calculate relative risks (RRs) and their 95\% confidence intervals (CIs). The funnel plot methods of Egger's test were used to assess publication bias. We performed subgroup analysis according to study quality, duration of the ethanol lock, disease type and CRBI definition. Sensitivity analysis was conducted to determine the stability of the meta-analysis results using Stata 12.0 software.

\section{Results}

\section{Characteristics of the included studies}

The initial results of databasesearchingproduced 461 records and 10 studies $[6-8,10-16]$ that met the inclusion criteria and were ultimately included after screening and reviewing by the authors. The selection flowchart is shown in Fig. 1. Reasons for the exclusion of 36 studies in the literature screening process are presented in Additional file 1.

The characteristics of the 10 included trials are listed in Table 1. A total of 2760 patients were 


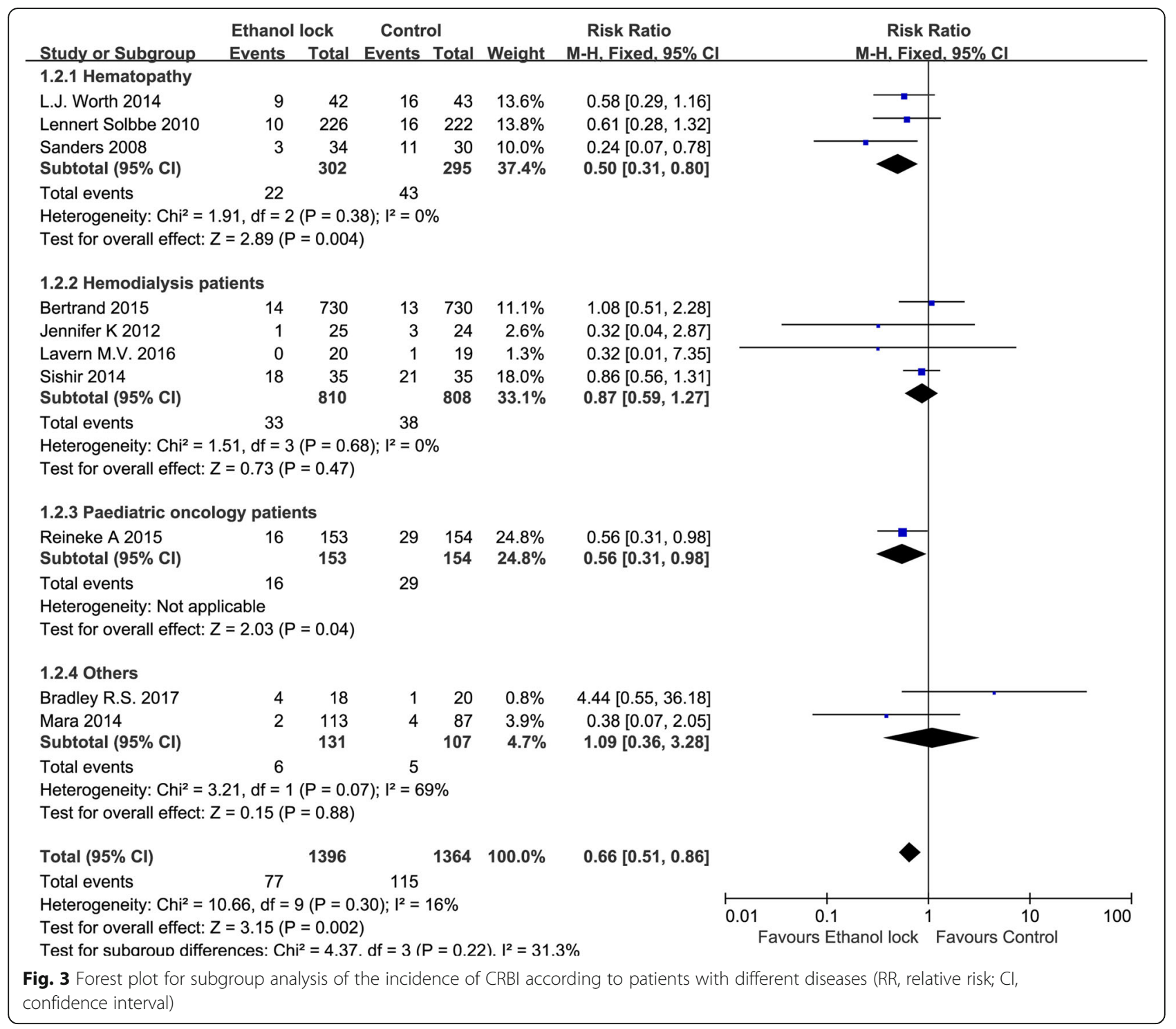

included in the meta-analysis, among whom1396receivedanintervention with ethanol locks. Three studies $[10,11,16]$ included only patients with hematological diseases, and 4 included hemodialysis patient $[6,7$, 13, 15]. Pediatric oncology patients were included only in one study [8], and the remaining two studies involved home parenteral nutrition patients [12] or those after major heart surgery [9].

\section{Risk of bias}

There were seven studies $[6-8,10-13]$ that were considered to have a low risk of bias for "Random sequence generation" and "Allocation concealment." "Blinding of participants and personnel" was judged to have a low risk of bias in five studies $[6,8,10-12]$ and a high risk in two studies [7, 13]. There was only one study that was deemed to have a low risk of bias for the item "Blinding of outcome assessment" [11]. For "Incomplete outcome data", six studies had a low risk of bias $[6,7,10-13]$ and three a high risk $[8,14$, 16]. There were seven studies $[7,8,10,11,13,14$, 16] that could be judged as having a low risk of bias in the item "selective reporting." The risk of bias assessment results are shown in Fig. 2.

\section{CRBI}

Definitions of CRBI among the included studies are shown in the Table 1, and a positive blood culture was necessary to diagnose CRBI $[17,18]$. All included studies reported the incidence of CRBI. The total pooled results showed that there was a significant difference between ethanol locks and conventional catheter-care (RR $0.66,95 \%$ CI 0.51 to 0.86 ), without 
Table 2 the pathogens involved in the infections

\begin{tabular}{|c|c|c|}
\hline NO. & Ethanol lock(n) & Control(n) \\
\hline $\begin{array}{l}\text { Bradley R.S. } \\
2017 \text { [12] }\end{array}$ & $\begin{array}{l}\text { Candida species(2); Staphylococcus species(1); } \\
\text { Escherichia coli plus Klebsiella species plus Pseudomonas(1). }\end{array}$ & Unidentified gram positive cocci \\
\hline $\begin{array}{l}\text { Lavern M.V. } \\
2016 \text { [7] }\end{array}$ & NA & $\begin{array}{l}\text { Klebsiella } \\
\text { Pneumonia }\end{array}$ \\
\hline $\begin{array}{l}\text { Bertrand } \\
2015 \text { [6] }\end{array}$ & $\begin{array}{l}\text { Staphylococcus epidermidis(20) } \\
\text { Staphylococcus aureus(2) } \\
\text { Enterococcus species (0) } \\
\text { Other coagulase negative Staphylococci(31) } \\
\text { Other Gram-positive (5) } \\
\text { Escherichia coli (2) } \\
\text { Proteus species (0) } \\
\text { Pseudomonas aeruginosa (10) } \\
\text { Enterobacterspecies (2) } \\
\text { Other Gram-negative (2) } \\
\text { Fungi (5) } \\
\text { Polymicrobial(20) }\end{array}$ & $\begin{array}{l}\text { Staphylococcus epidermidis(9) } \\
\text { Staphylococcus aureus(0) } \\
\text { Enterococcus species (1) } \\
\text { Other coagulase negative Staphylococci(27) } \\
\text { Other Gram-positive (6) } \\
\text { Escherichia coli (1) } \\
\text { Proteus species (2) } \\
\text { Pseudomonas aeruginosa (9) } \\
\text { Enterobacterspecies (0) } \\
\text { Other Gram-negative (3) } \\
\text { Fungi (3) } \\
\text { Polymicrobial(17) }\end{array}$ \\
\hline $\begin{array}{l}\text { Reineke A } \\
2015 \text { [8] }\end{array}$ & $\begin{array}{l}\text { Staphylococcus epidermidis(2) } \\
\text { Other coagulase-negative Staphylococc(4) } \\
\text { Staphylococcus aureus(0) } \\
\text { Streptococcus parasanguis(1) } \\
\text { Other alpha-haemolytic streptococci (1) } \\
\text { Enterococcus faecalis(0) } \\
\text { Bacillus sp.(0) } \\
\text { Streptomyces sp.(0) } \\
\text { Escherichia coli(1) } \\
\text { Citrobacter freundii(1) } \\
\text { Brevundimonas vesicularis(1) } \\
\text { Gram-negative rod (1) } \\
\text { Polymicrobial(3) } \\
\text { Candida sp.(1) }\end{array}$ & $\begin{array}{l}\text { Staphylococcus epidermidis(1) } \\
\text { Other coagulase-negative Staphylococc(8) } \\
\text { Staphylococcus aureus(2) } \\
\text { Streptococcus parasanguis(0) } \\
\text { Other alpha-haemolytic streptococci (0) } \\
\text { Enterococcus faecalis(1) } \\
\text { Bacillus sp.(2) } \\
\text { Streptomyces sp.(1) } \\
\text { Escherichia coli(3) } \\
\text { Citrobacter freundii(0) } \\
\text { Brevundimonas vesicularis(0) } \\
\text { Gram-negative rod (0) } \\
\text { Polymicrobial(0) } \\
\text { Candida sp.(2) }\end{array}$ \\
\hline
\end{tabular}

L.J. Worth Coagulase-negative Staphylococcus spp. (3),

2014 [16] Staphylococcus aureus (1),

Listeria monocytogenes (1), Klebsiella pneumoniae (2), Escherichia coli (1), Pseudomonas aeruginosa (1), E. coli (2)and C. glabrata (1).

Sishir

2014 [15]

Mara 2014 [14] Gram positive cocci(0)

Enterobacteriaceae(2)

Gram negative non-fermenting rods( 0 ) Fungi $(0)$

Jennifer K 2012 Staphylococcus aureus(1)

[13]

Lennert Solbbe $\mathrm{n}=$ episodes

2010 [11] Coagulase-negative staphylococci.(49)

Other skin colonizers(2)

Staphylococcus aureus(2)

Other gram-positive cocci(12)

Gram-negatives(4)

Polymicrobial(20)

Yeasts(2)

Sanders

2008 [10] $\mathrm{n}=$ episodes

A-haemolytic Streptococcus(1)

Streptococcus group B (agalactiae)(0),

S. epidermidis(0),

Staphylococcus aureus(0),

Stomatococcus rothia mucilaginosa(1),

Escherichia coli(1),

Pseudomonas aeruginosa(0),

Klebsiella pneumoniae(0),

non-speciated Gram-negative bacilli(0).
Coagulase-negative Staphylococcus spp. (7), Staphylococcus aureus (1), Enterococcus faecium (1), Klebsiella pneumoniae (2), Escherichia coli (1), Pseudomonas aeruginosa (1), Enterobacter cloacae(1), E. coli and E. faecium (1), and Candida parapsilosis (1).

NA

Gram positive cocci(1)

Enterobacteriaceae(2)

Gram negative non-fermenting rods(1)

Fungi(0)

Staphylococcus aureus(1)

Enterobacter cloacae(1)

Staphylococcus hominis

(1)

$\mathrm{n}=$ episodes

Coagulase-negative staphylococci.(57)

Other skin colonizers(2)

Staphylococcus aureus(3)

Other gram-positive cocci(10)

Gram-negatives(5)

Polymicrobial(13)

Yeasts(1)

$\mathrm{n}=$ episodes

A-haemolytic Streptococcus(1)

Streptococcus group B (agalactiae)(1),

S. epidermidis(3),

Staphylococcus aureus(1),

Stomatococcus rothia mucilaginosa(0),

Escherichia coli(4).

Pseudomonas aeruginosa(1),

Klebsiella pneumoniae(1),

non-speciated Gram-negative bacilli(1). 
significant heterogeneity $\left(\mathrm{I}^{2}=16 \%\right.$, Fig. 3$)$. The pathogens involved in the reported infections are shown in Table 2.

Subgroup analysis showed that an ethanol lock can reduce the incidence of $\mathrm{CRBI}$ in patients with hematological diseases (RR 0.50, 95\% CI 0.31 to 0.80 , $\mathrm{I}^{2}=0 \%$, Fig. 3). There was no significant difference between ethanol lock and conventional catheter care groups (RR 0.87, 95\% CI 0.59 to 1.27) among hemodialysis patients, without significant heterogeneity $\left(\mathrm{I}^{2}=0 \%\right.$, Fig. 3$)$. In addition, an ethanol lock was more effective than traditional controls at preventing CRBI in pediatric oncology patients (RR 0.56, 95\% CI 0.31 to 0.98 , Fig. 3). Meta-analysis of high-quality studies (random sequence generation, allocation concealment and blinding of participants and personnel in the study can be evaluated as low risk) showed that an ethanol lock significantly reduced CRBI in patients with central venous catheters (RR 0.66, 95\% CI 0.47 to 0.94 ), and meta-analysis of low-quality studies also suggested a significant difference in the incidence of CRBI between ethanol lock and control groups (RR 0.66, 95\% CI 0.46to 0.95) (Fig. 4). Subgroup analysis indicated that there was a significant difference between 2-h ethanol lock and conventional catheter care groups (RR $0.4995 \%$ CI 0.33 to 0.73 ), without significant heterogeneity $\left(\mathrm{I}^{2}=0 \%\right.$, Fig. 5). There was no significant difference between less than 20-min ethanol lock and conventional catheter care groups (RR 0.84, 95\% CI 0.59 to 1.19 ), again without significant heterogeneity $\left(\mathrm{I}^{2}=0 \%\right.$, Fig. 5), or 48-hour ethanol lock and conventional catheter care groups (RR 1.29, 95\% CI 0.37 to 4.47).Meta-analysis of studies with a strict CRBI definition revealed that an ethanol lock can significantly prevent CRBI (RR $0.61,95 \%$ CI $0.42-$ 0.89 ),though pooled analysis of studies with a less strict CRBI definition suggested no significant change in the incidence of CRBI between ethanol lock and control lock groups (RR 0.65, 95\% CI 0.39-1.07) (Fig. 6).

Sensitivity analysis results showed that the results were relatively consistent (Fig. 7), and no obvious publication bias was detected, as based on Eggers' funnel plots (Fig. 8).

\section{Adverse events}

The results of meta-analysis involving adverse events are depicted in Fig. 7. An ethanol lock did not significantly increase the incidence of a thrombus (RR 1.05, $95 \%$ CI 0.51 to 2.18 ) or mortality (RR $0.99,95 \%$ CI 0.90 to 1.08 ) but did increase nausea (RR 1.54, 95\% CI 1.01 to 2.35), dizziness (RR $4.21,95 \%$ CI 2.40 to 7.39), and blushing ( $R R$ 3.27, 95\% CI 2.05 to 5.22) and altered taste (RR 2.61, 95\% CI 1.93 to 3.54) (Fig. 9).

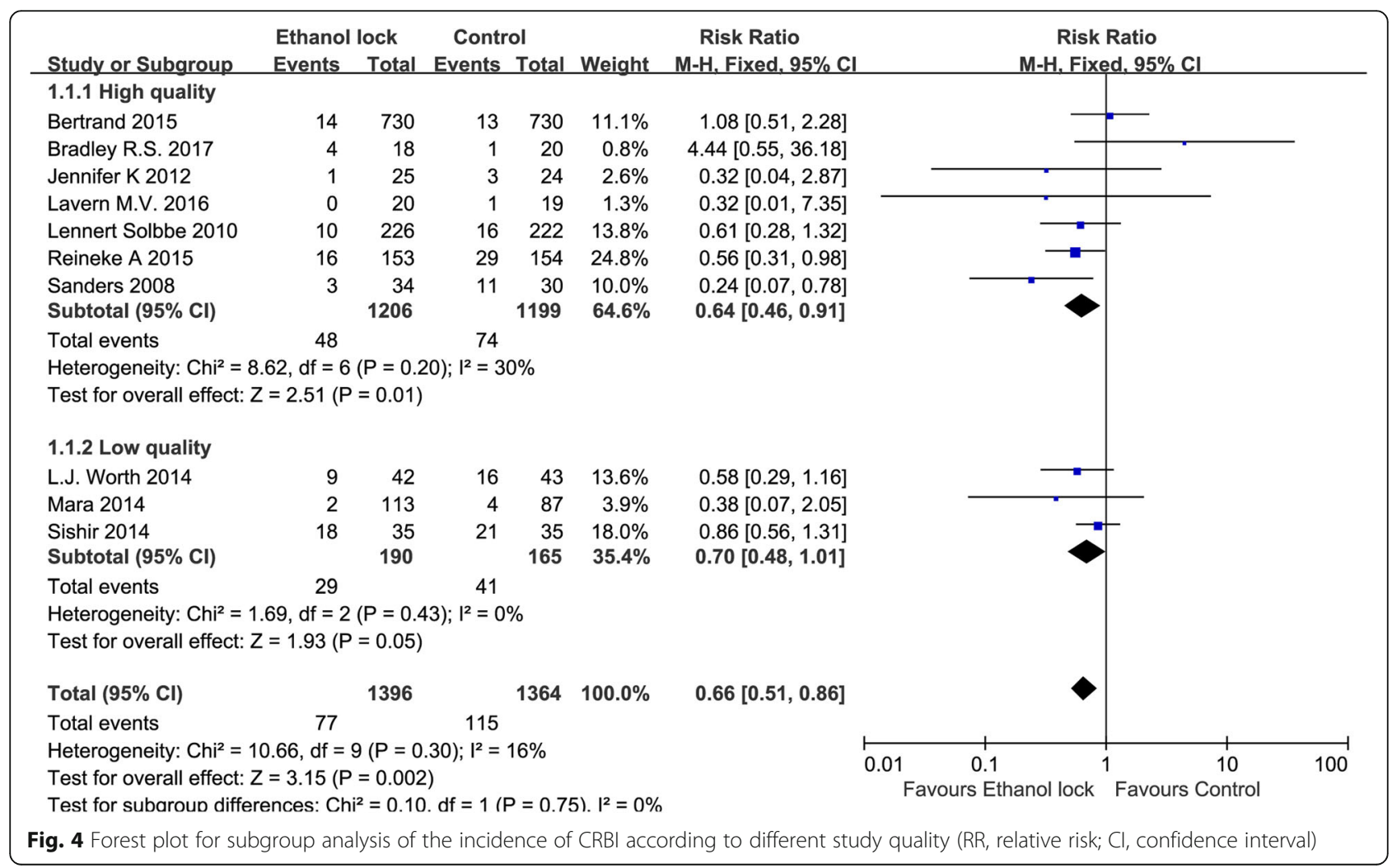




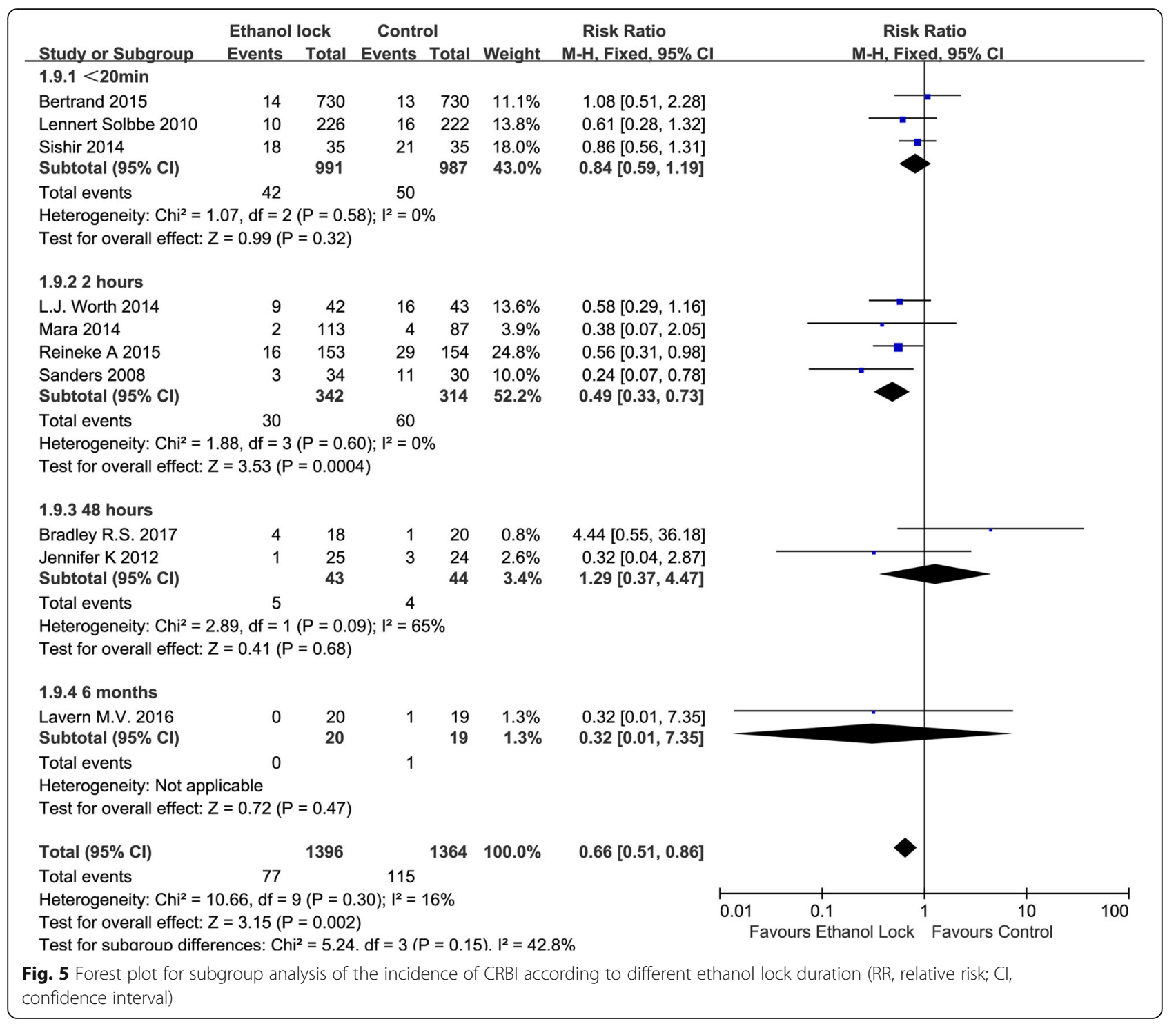

\section{Discussion}

Our meta-analysis first identified the efficacy of ethanol locks in preventing CRBIs. We found that ethanol locks significantly reduced the incidence of CRBI (RR 0.66, 95\% CI 0.51-0.86). Subgroup analysis suggested that an ethanol lock significantly decreased CRBI incidence in patients with hematological diseases (RR $0.50,95 \%$ CI $0.31-0.80$ ), and a meta-analysis that only included high-quality studies showed that an ethanol lock significantly reduced CRBI incidence (RR 0.64, 95\% CI 0.46-0.91). A 2-h ethanol lock diminished the frequency of CRBI, but a shorter (less than $20 \mathrm{~min}$ ) ethanol lock did not decrease infection risk. Additionally, a meta-analysis of studies with strict CRBI definitions showed that an ethanol lock can significantly prevent a CRBI. Although an ethanol lock did not significantly increase thrombus and mortality rates, it did increase certain adverse reactions, such as nausea, dizziness, blushing and altered taste, in patients.

Tunneled CVCs are used for long-term venous access to deliver blood and blood products, chemotherapy and parenteral nutrition. The prevalence of CRBI is high in patients with indwelling CVCs, which also leads to a severe result [19], and internal colonization in long-term tunneled CVCs more frequently contributes to bacteremia $[20,21]$. Many methods have been employed to prevent catheter-related sepsis, including the use of cutaneous antisepsis at the time of insertion, catheter tunneling, intraluminal antibiotic locks, antiseptic hubs and anti-microbial coating of catheters $[22,23]$. However, these methods may fail to decrease the risk of infection and may instead increase the risk of hypersensitivity and development of anti-microbial resistance. Ethanol-based catheter locks may provide a 


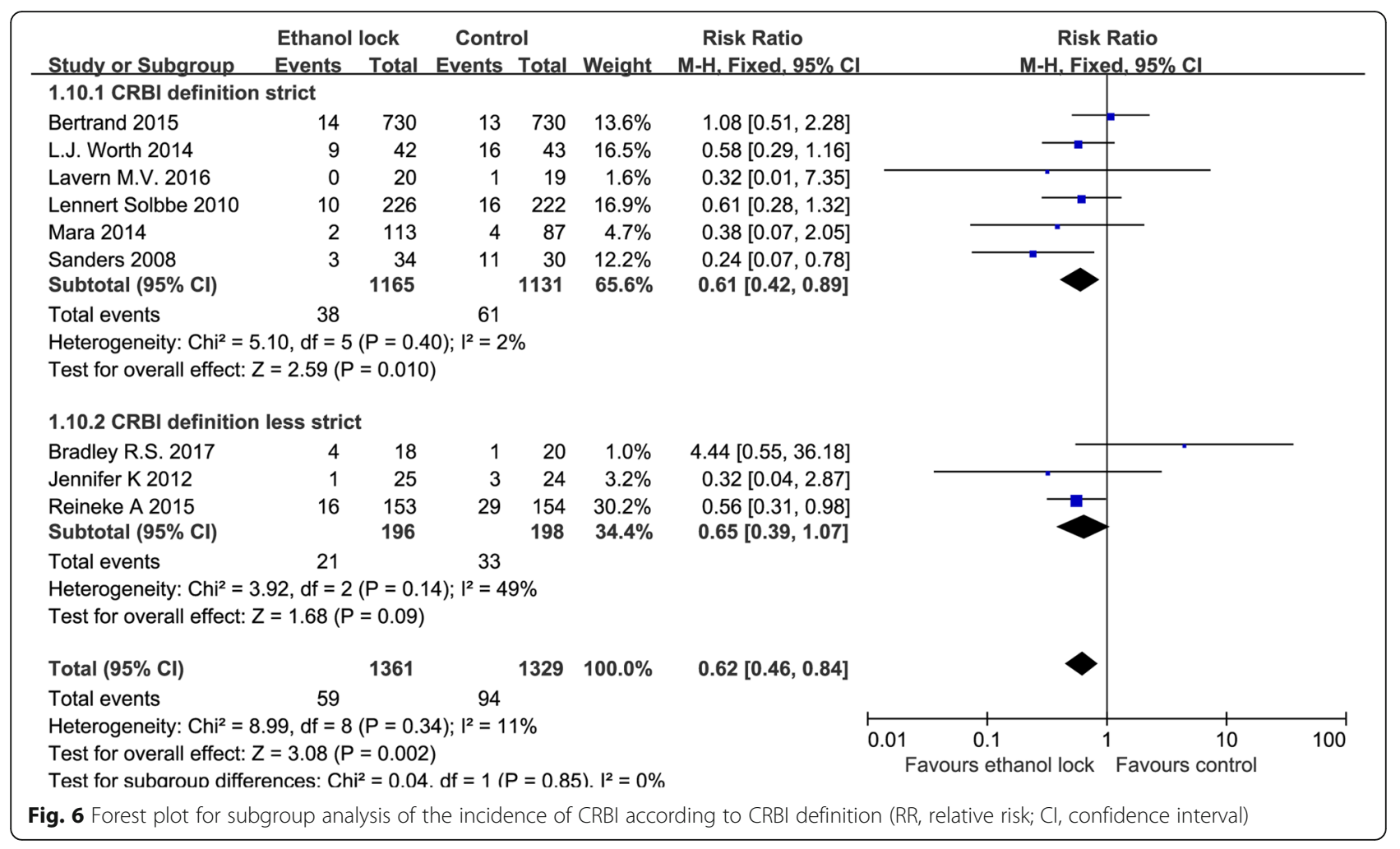

better alternative because ethanol is a widely used antiseptic with no known acquired resistance [24]. A meta-analysis of observational studies found that ethanol locks are effective alternatives to heparin locks for preventing CRBI in pediatric patients with intestinal failure [25], with the ethanol lock dwell time ranging from more than $2 \mathrm{~h}$ per day to $4 \mathrm{~h}$ 3 days per week.
To the best of our knowledge, this report describes the first meta-analysis of RCTs to investigate the efficacy of ethanol locks in the prevention of CRBI. Ten RCTs were included in our meta-analysis, and the high quality of the included studies enhances current evidence. Moreover, we performed subgroup analysis based on differences in study quality, duration of the ethanol lock and disease type.

Meta-analysis fixed-effects estimates (exponential form)

Study ommited

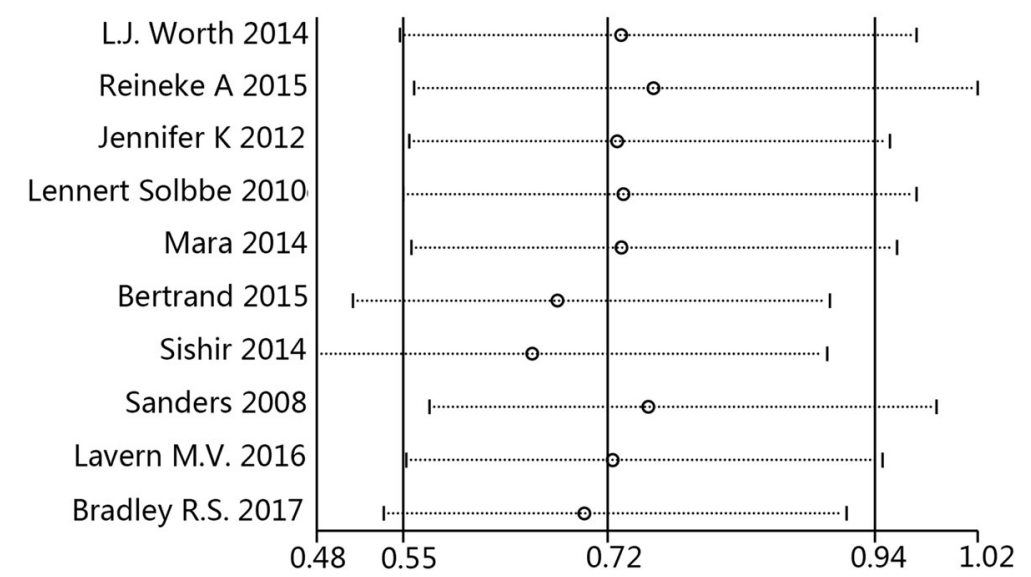

Fig. 7 Sensitivity analysis of CRBI results 


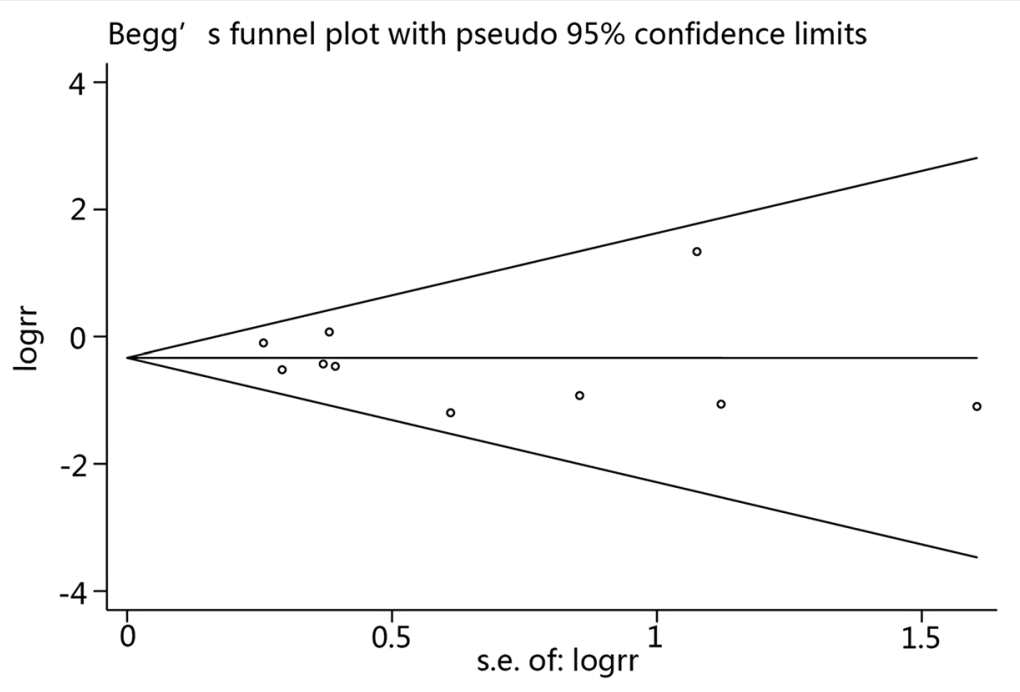

Fig. 8 Begg's funnel plot

Three studies reported the incidence of CRBI in patients with hematological diseases whose immune system was suppressed, and pooled analysis of these three studies suggested that an ethanol lock significantly reduces CRBI in immunosuppressed patients. Despite no significant difference according to the subgroup analysis in CRBI in hemodialysis patients, immune status or homeostasis may have an effect on the incidence of CRBI with an ethanol lock, which can result in bias among studies. In addition, to exclude bias by differences in study quality, subgroup analysis of relative high-quality or low-quality studies was performed, and the results suggested that an ethanol lock can significantly reduce CRBI risk. However, our definition of high-quality study was different from the Cochran high-quality trial definition; the latter requires all seven domains of the risk of bias assessment tool to be at "low risk of bias". Consequently, our subgroup analysis results regarding study quality are not very accurate. More high-quality studies that meet the Cochran definition are needed.

Three studies reported that the CVCs were locked with ethanol for $2 \mathrm{~min}, 15 \mathrm{~min}$, and $20 \mathrm{~min}$. The incidences of CRBI in these studies were determined by pooled analysis, though the short time frame for the ethanol lock did not effectively prevent CRBIs. In addition, the follow-up times were only $48 \mathrm{~h}$, or shorter in the study by Bertrand et al., who used a 2-min ethanol lock. In combination with the low incidence of CRBI in that study, this situation might have contributed to the low efficiency in calculating a difference. In the remaining two studies, ethanol locks exhibited a tendency to prevent CRBIs, though without statistical significance. Interestingly, our findings showed that a 2-h ethanol lock (2-h duration of the lock) significantly decreased the frequency of CRBI. The preferable baseline similarity in the included four studies with a 2-h ethanol lock also enhanced the reliability of our meta-analysis results. Raadet al. found that prolonged exposure to lock solutions containing $25 \%$ ethanol in ethylenediaminetetraacetic acid (EDTA) can effectively enhance antibacterial activity in the silicone disk biofilm colonization model [26]. We did not find that a 48-h or 6-month lock can effectively prevent CRBI in our meta-analysis, and this may be due to their smaller size.

The strict definition of CRBI is such that clinical symptoms are not included and only blood culture results are used. Interestingly, meta-analysis of the studies with a strict CRBI definition showed that an ethanol lock can significantly prevent CRBI; however, this was not the result of pooled analysis of studies with a less strict CRBI definition. This finding may be the reason why a less strict CRBI definition reduced the sample weight. Because there was one study that included pediatric patients, the subgroup analysis on age was achieved by sensitivity analysis. Sensitivity analysis showed the results of pooled analysis were relatively stable. Statistical significance was lost when the trial by Reineke et al. was removed, which was due to the large sample size (307) of the study, resulting in its larger weight in the pooled result. It is noteworthy that an ethanol lock did not reduce the incidence of mortality, but there was a notable lack of mortality data in most of the trials. No obvious publication bias was detected, enhancing the value of the meta-analysis results. In addition, based on data of the pathogens involved in the infections, we determined that Staphylococcus has an important role as a cause of CRBI. 
a

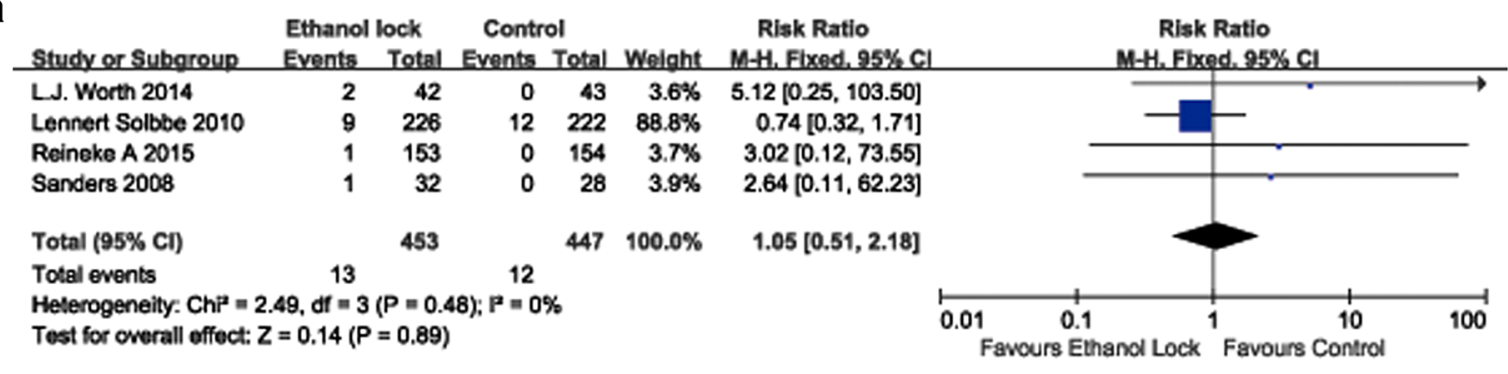

b

\begin{tabular}{lrrrrrrr} 
Study or Subgroup & Events & Total & Events & Total & Woight & M-H. Fixod. 95\% C \\
\hline L.J. Worth 2014 & 1 & 42 & 0 & 43 & $1.6 \%$ & $3.07[0.13,73.30]$ \\
Lennert Solbbe 2010 & 20 & 226 & 17 & 222 & $54.0 \%$ & $1.16[0.62,2.15]$ \\
Reineke A 2015 & 28 & 147 & 14 & 144 & $44.5 \%$ & $1.96[1.08,3.57]$ \\
& & 415 & & 409 & $100.0 \%$ & $1.54[1.01,2.35]$ \\
Total (95\% CI) & 49 & & 31 & & &
\end{tabular}

Heterogeneity: $\mathrm{Ch}^{\mathrm{i}}=1.63, \mathrm{df}=2(\mathrm{P}=0.44) ; \mathrm{R}^{2}=0 \%$

Test for owerall effect: $Z=2.01(P=0.04)$

C

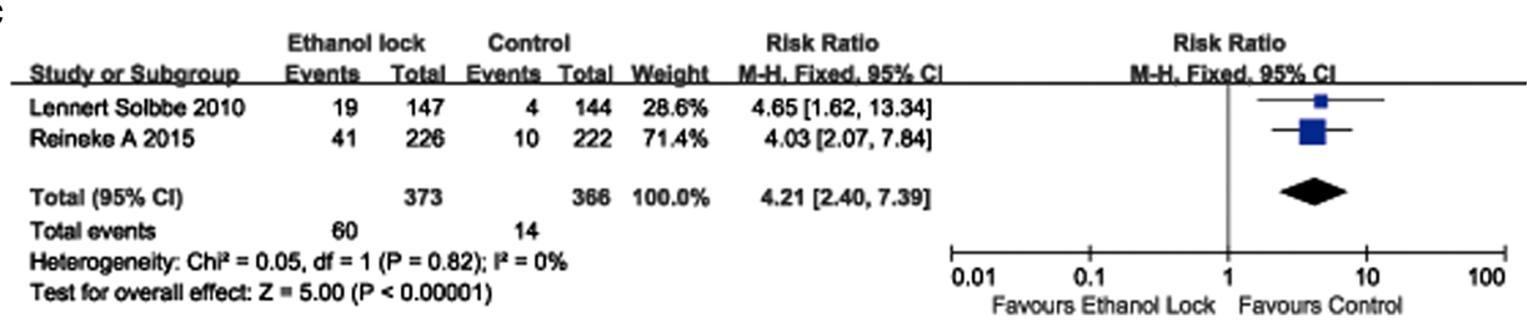

d

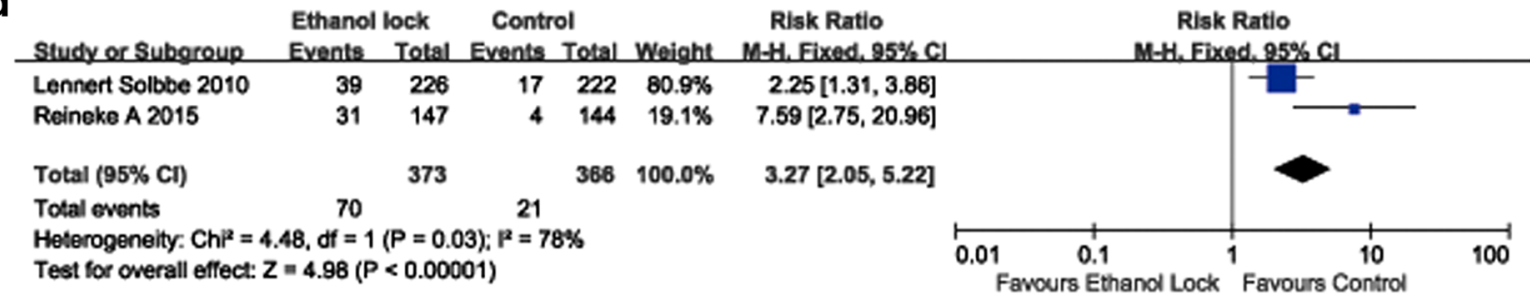

e

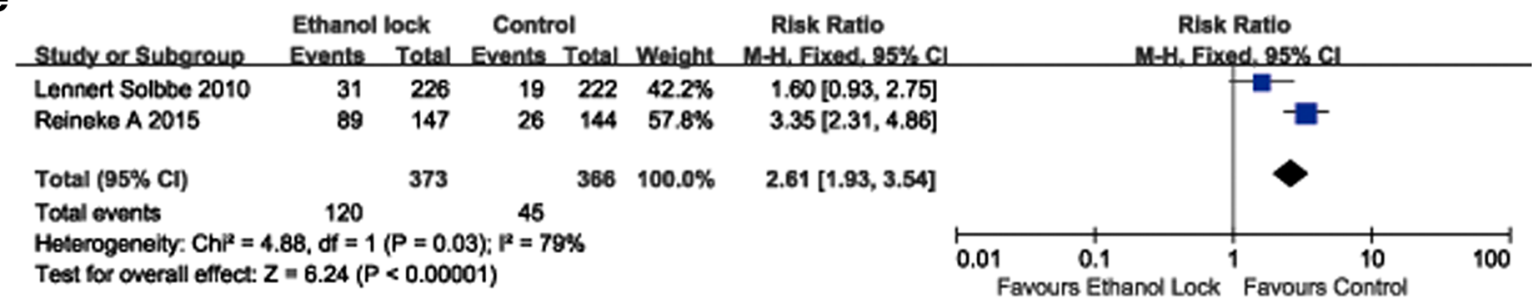

f

\begin{tabular}{|c|c|c|c|c|c|c|c|c|}
\hline \multirow{2}{*}{ Study or Subgroup } & \multicolumn{2}{|c|}{ Ethanol lock } & \multicolumn{2}{|c|}{ Control } & & \multirow{2}{*}{$\begin{array}{l}\text { Risk Ratio } \\
\text { M-th. Flxod. } 95 \% \mathrm{Cl}\end{array}$} & \multirow{2}{*}{\multicolumn{2}{|c|}{$\begin{array}{c}\text { Risk Ratio } \\
\text { M-H,Flod, } 95 \% \text { CI }\end{array}$}} \\
\hline & Events & Total & Events & Total & Woight & & & \\
\hline & 0 & 153 & 0 & 154 & & Not estimable & & \\
\hline Lennert Solbbe 2010 & 7 & 226 & 5 & 222 & $1.0 \%$ & $1.38[0.44,4.27]$ & & \\
\hline Reineke A 2015 & 717 & 1460 & 364 & 730 & $99.0 \%$ & $0.88[0.90,1.08]$ & & \\
\hline Total $(25 \% \mathrm{Cl})$ & & 1839 & & 1106 & $100.0 \%$ & $0.99[0.90,1.08]$ & 4 & \\
\hline Total events & 724 & & 369 & & & & & \\
\hline $\begin{array}{l}\text { Helerogenaity: Chi = } \\
\text { Test for owerall effect: }\end{array}$ & $\begin{array}{l}33, d f=1 \\
=0.24(P\end{array}$ & $\begin{array}{l}(P=0.5 \\
=0.81)\end{array}$ & $6) ; R^{2}=$ & & & & $0.010 .1 \quad 1$ & control \\
\hline
\end{tabular}

Fig. 9 Forest plot for adverse events including thrombus (a), nausea (b), dizziness (c), blushing (d), altered taste (e) and mortality (f) 
There were also several limitations to our meta-analysis. First, we included only the abstract of studies for which we could not find the full text. Second, although a significant difference was detected in CRBI between ethanol lock and control lock groups according to subgroup analysis, the analyzable number of studies was low, which can result in bias risk. Third, very small differences in catheter type, such as dialysis catheter, and inserting catheters for parenteral nutrition may also lead to bias risk. Fourth, we did not find a significant difference in the incidence of CRBI between ethanol locks and control locks in hemodialysis patients, which was according to meta-analysis results of four studies, and the incidence of CRBI can be influenced by disturbed homeostasis. Sixth, the inclusion of the pediatric population of one study with a large sample might represent a small bias (adult and pediatric populations are different). Finally, patients with an ethanol lock may have certain adverse reactions, such as nausea, dizziness, blushing and altered taste, which might becaused by the ethanol lock solution entering into the bloodstream during catheter use.

\section{Conclusions}

Ethanol locks may play a role in preventing CRBI, though the strength of evidence is limited by the number of studies in the analysis.

\section{Additional file}

Additional file 1: Reasons for the exclusion of 36 studies in the literature screening process. (DOCX $67 \mathrm{~kb}$ )

\begin{abstract}
Abbreviations
Cl: Confidence interval; CRBI: Catheter-related bloodstream infection; CVC: Central venous catheters; DCs: Dialysis catheters; MHS: Major Heart Surgery; PRISMA: Preferred reporting items of the systematic review and meta-analyses; RCTs: Randomized controlled trials; RR: Relative risk
\end{abstract}

\section{Availability of data and materials}

The datasets used and/or analyzed during the current study are available from the corresponding author on reasonable request.

\section{Authors' contributions}

$\mathrm{PZ}$ and $\mathrm{JH}-\mathrm{L}$ participated in the project development, literature search, statistical analysis, and manuscript writing; XJ-S and XH-W did the project development. All authors read and approved the final manuscript.

\section{Ethics approval and consent to participate}

Not applicable.

\section{Consent for publication}

Not Applicable as our manuscript is a meta-analysis.

\section{Competing interests}

The authors declare that they have no competing interests.

\section{Publisher's Note}

Springer Nature remains neutral with regard to jurisdictional claims in published maps and institutional affiliations.
Received: 20 January 2018 Accepted: 24 June 2018

Published online: 24 July 2018

\section{References}

1. Eggimann P. Prevention of intravascular catheter infection. Curr Opin Infect Dis. 2007;20(4):360-9.

2. Worth LJ, McLaws ML. Is it possible to achieve a target of zero central line associated bloodstream infections? Curr Opin Infect Dis. 2012;25(6):650-7.

3. Vassallo M, Dunais B, Roger PM. Antimicrobial lock therapy in central-line associated bloodstream infections: a systematic review. Infection. 2015;43(4): 389-98.

4. Labriola L, Crott R, Jadoul M. Preventing haemodialysis catheter-related bacteraemia with an antimicrobial lock solution: a meta-analysis of prospective randomized trials. Nephrol Dial Transplant. 2008;23(5):1666-72.

5. Tan M, Lau J, Guglielmo BJ. Ethanol locks in the prevention and treatment of catheter-elated bloodstream infections. Ann Pharmacother. 2014;48(5): 607-15.

6. Souweine B, Lautrette A, Gruson D, Canet E, Klouche K, Argaud L, Bohe J, Garrouste-Orgeas M, Mariat C, Vincent F, et al. Ethanol lock and risk of hemodialysis catheter infection in critically ill patients. A randomized controlled trial. Am J Respir Crit Care Med. 2015;191(9):1024-32.

7. Vercaigne LM, Allan DR, Armstrong SW, Zacharias JM, Miller LM. An ethanol/ sodium citrate locking solution compared to heparin to prevent hemodialysis catheter-related infections: a randomized pilot study. J Vasc Access. 2016;17(1):55-62.

8. Schoot RA, van Ommen $\mathrm{CH}$, Stijnen $\mathrm{T}$, Tissing WJ, Michiels E, Abbink FC, Raphael MF, Heij HA, Lieverst JA, Spanjaard L, et al. Prevention of central venous catheter-associated bloodstream infections in paediatric oncology patients using 70\% ethanol locks: a randomised controlled multi-Centre trial. Eur J Cancer. 2015;51(14):2031-8.

9. Hannan MM, O'Sullivan KE, Higgins AM, Murphy AM, McCarthy J, Ryan E, Hurley JP. The Combined Impact of Surgical Team Education and Chlorhexidine 2\% Alcohol on the Reduction of Surgical Site Infection following Cardiac Surgery. Surgical Infections. 2015;16(6):799-805.

10. Sanders J, Pithie A, Ganly P, Surgenor L, Wilson R, Merriman E, Loudon G, Judkins R, Chambers S. A prospective double-blind randomized trial comparing intraluminal ethanol with heparinized saline for the prevention of catheter-associated bloodstream infection in immunosuppressed haematology patients. J Antimicrob Chemother. 2008;62(4):809-15.

11. Slobbe L, Doorduijn JK, Lugtenburg PJ, Barzouhi AE, Boersma E, van Leeuwen WB, Rijnders BJA. Prevention of catheter-related bacteremia with a daily ethanol lock in patients with tunnelled catheters: a randomized, placebo-controlled trial. PLoS One. 2010;5(5)

12. Salonen BR, Bonnes SL, Vallumsetla N, Varayil JE, Mundi MS, Hurt RT. A prospective double blind randomized controlled study on the use of ethanol locks in HPN patients. Clin Nutr. 2017;37(4):1181-85.

13. Broom JK, Krishnasamy R, Hawley CM, Playford EG, Johnson DW. A randomised controlled trial of heparin versus EthAnol lock THerapY for the prevention of catheter associated infecTion in Haemodialysis patients-the HEALTHY-CATH trial. BMC Nephrol. 2012;13:146.

14. Perez-Granda MJ, Barrio JM, Munoz P, Hortal J, Rincon C, Rabadan PM, Pernia MS, Bouza E. Ethanol lock therapy (E-lock) in the prevention of catheter-related bloodstream infections (CR-BSI) after major heart surgery (MHS): a randomized clinical trial. PLoS One. 2014;9(3):e91838.

15. Sishir G, Bhupeshkumar K, Umapati H, Kalpesh G, Mohan R. To study the efficacy of intraluminal $70 \%$ ethanol vs heparin lock prior to hemodialysis in prevention of infections in non-tunneled hemodialysis catheters: a randomised study. Nephrology. 2014;19:181-2.

16. Worth LJ, Slavin MA, Heath S, Szer J, Grigg AP. Ethanol versus heparin locks for the prevention of central venous catheter-associated bloodstream infections: a randomized trial in adult haematology patients with Hickman devices. J Hosp Infect. 2014;88(1):48-51.

17. O'Grady NP, Alexander M, Dellinger EP, Gerberding JL, Heard SO, Maki DG, Masur H, RD MC, Mermel LA, Pearson ML, et al. Guidelines for the prevention of intravascular catheter-related infections. The hospital infection control practices advisory committee, Center for Disease Control and Prevention, U.S. Pediatrics. 2002;110(5):e51.

18. Mermel LA, Allon M, Bouza E, Craven DE, Flynn P, O'Grady NP, Raad II, Rijnders BJ, Sherertz RJ, Warren DK. Clinical practice guidelines for the diagnosis and management of intravascular catheter-related infection: 2009 
update by the Infectious Diseases Society of America. Clin Infect Dis. 2009; 49:1):1-45.

19. Hajjej Z, Nasri M, Sellami W, Gharsallah H, Labben I, Ferjani M. Incidence, risk factors and microbiology of central vascular catheter-related bloodstream infection in an intensive care unit. J Infect Chemother. 2014;20(3-4):163-8.

20. Buchman AL, Spapperi J, Leopold P. A new central venous catheter cap: decreased microbial growth and risk for catheter-related bloodstream infection. J Vasc Access. 2009;10(1):11-21.

21. Decicco M, Chiaradia V, Veronesi A, Santini G, Panarello G, Fracasso A, Testa $V$, Tesio F. Source and route of microbial colonization of parenteral-nutrition catheters. Lancet. 1989;2(8674):1258-61.

22. Sawyer M, Weeks K, Goeschel CA, Thompson DA, Berenholtz SM, Marsteller JA, Lubomski LH, Cosgrove SE, Winters BD, Murphy DJ, et al. Using evidence, rigorous measurement, and collaboration to eliminate central catheterassociated bloodstream infections. Crit Care Med. 2010:38(8):S292-8.

23. Crnich CJ, Maki DG. The promise of novel technology for the prevention of intravascular device-related bloodstream infection. II. Long-term devices. Clin Infect Dis. 2002;34(10):1362-8.

24. Metcalf SCL, Chambers ST, Pithie AD. Use of ethanol locks to prevent recurrent central line sepsis. J Infect. 2004;49(1):20-2.

25. Oliveira C, Nasr A, Brindle M, Wales PW. Ethanol locks to prevent catheterrelated bloodstream infections in parenteral nutrition: a meta-analysis. Pediatrics. 2012;129(2):318-29.

26. Raad I, Hanna H, Dvorak T, Chaiban G, Hachem R. Optimal antimicrobial catheter lock solution, using different combinations of minocycline, EDTA, and 25-percent ethanol, rapidly eradicates organisms embedded in biofilm. Antimicrob Agents Chemother. 2007;51(1):78-83.

\section{Ready to submit your research? Choose BMC and benefit from:}

- fast, convenient online submission

- thorough peer review by experienced researchers in your field

- rapid publication on acceptance

- support for research data, including large and complex data types

- gold Open Access which fosters wider collaboration and increased citations

- maximum visibility for your research: over $100 \mathrm{M}$ website views per year

At BMC, research is always in progress.

Learn more biomedcentral.com/submissions 